\title{
Effect of Ectoin a Natural Ingredient on Skin Hydration and Skin Moisture Content
}

\author{
Sae-Rom Lee ${ }^{1}$, Young-Sam Kim ${ }^{2 *}$ \\ ${ }^{1}$ Department of Cosmetology, Graduate School of Engineering, Konkuk University, Seoul, Korea \\ ${ }^{2}$ Department of Image Industry, Graduate School of Engineering, Konkuk University, Seoul, Korea
}

\author{
*Corresponding author: Young-Sam Kim, \\ Department of Image Industry, Graduate \\ School of Engineering, Konkuk University, 120 \\ Neungdong-ro Gwangjin-gu, Seoul 05029, \\ Korea \\ Tel.: +82 24503595 \\ Email: gracehelen@konkuk.ac.kr
}

\section{Received July 10, 2018}

Revised July 23, 2018

Accepted July 26, 2018

Published September 30, 2018

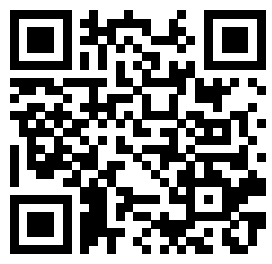

\begin{abstract}
Purpose: The purpose of this study was to examine the overall effects of a natural ingredient Ectoin on moisture content, pore size, and tone of the skin. Methods: Ectoin was used for the production of a foam cleanser, toner, cream, and lotion. Experimental and control groups were provided with cosmetic samples with or without Ectoin, respectively, and instructed to apply them to their face twice a day in the morning and evening over a 4-week period. The data collected in this study were analyzed using the statistical software SPSS 24.0 for Windows. Results: Regarding oil contents, the control group showed increased oil contents at T- and U-zones, whereas the experimental group showed decreased oil contents at T-zones and increased oil contents at U-zones. Regarding moisture, although moisture contents increased in both the groups after the experiment, the experimental group exhibited a higher increase in moisture content than the control group across all facial areas. The experimental group showed statistically significant increase in moisture content on all facial areas excluding the chin. Regarding transepidermal water loss (TEWL), the control group exhibited increased TEWL values at all facial areas excluding the chin, whereas the experimental group showed decreased TEWL values at all facial areas. Regarding pore sizes, although the control group showed a pattern of alternate increase and decrease in pore sizes, the experimental group exhibited decrease in pore sizes at all facial areas. Regarding $\mathrm{pH}$ levels, both groups showed a normal $\mathrm{pH}$ range (4.5-6.5) before and after the experiment without any statistically significant changes. Regarding skin tone, the control group showed alternate increase and decrease in melanin, whereas the experimental group showed a statistically significant decrease in melanin on the left and right sides of the face. While both groups showed a reduction in red spots, the experimental group showed a greater extent of reduction in red spots than the control group. Conclusion: The above results indicate that the cream containing Ectoin as a natural ingredient has a positive effect on skin moisturizing and moisture, and it is confirmed to be a natural moisturizing raw material for cosmetics.
\end{abstract}

Keywords: Moisture, Transepidermal water loss, Ectoin, Moisturization, Natural ingredient

\section{Introduction}

현대의학과 생활수준이 향상되면서 건강하고 아름다운 외모 에 대한 관심이 집중되었고, 이에 따라 외모를 관리하는 사람들 이 증가하고 있다(Boelsma et al., 2001; Park et al., 2003). 외적 이미지 관리에는 다양한 부분이 있지만 그 중 가장 많은 관
심을 가지고 관리하는 부분은 피부관리이다. 뷰티 프로그램이 나 동영상, SNS 등을 통해 건강하고 깨끗한 피부를 위한 아이템 들이 연령대 구분 없이 주목을 받고 있다(Whang et al., 2010; Chang et al., 2007).

건강한 피부를 관리하는데 있어서 가장 이해해야 하는 부분 이 각질층이며, 각질층은 유·수분으로 구성되어 있는 피지보호 
막으로 덮여 있어 피부의 건조함을 막으며, 수분을 끌어당겨 촉 촉한 피부를 만들어 준다(Jablonski, 2012; Kim, 1996; Kang $\& \mathrm{Hahm}, 1996)$. 각질층은 피부의 보습기능과 많은 관련이 있 고, 외부환경으로부터 피부를 보호하는 장벽 역할을 한다(Kim et al., 2009). 또한 건강한 피부를 위해서는 피부의 수분 함량이 절대적이다. 수분 함량이 높을수록 피부가 촉촉해지고, 윤기 있 는 매끈한 피부로 보일 수 있다(Kang \& Hahm, 1993). 피부 표 피에 있는 각질층이 건조해질 수 있는 원인들은 많지만, 대표적 으로 환경오염과 초미세먼지와 같은 대기오염 문제 및 불규칙한 생활, 불균형한 식습관 등 여러 가지 원인들로 볼 수 있다(Kwon \& Choi, 2005; Kwon et al., 2013). 따라서 건강한 피부를 위 해서는 적절한 운동, 균형 잡힌 영양섭취, 충분한 숙면, 마사지, 1 일 1 팩 등 다양한 방법들이 있지만, 실생활에서 지키기 어려운 것들이 많다. 그 중 가장 편하면서 쉬운 방법은 보습력이 있는 화 장품을 사용하는 것이다.

보습제는 피부의 수분을 증가시켜 부드럽고 탄력 있는 건강한 피부가 되도록 도움을 줄 수 있다(Kwon et al., 2009; Sohn et al., 2004). 보습제의 성분은 피부 보습을 높이고, 수분이 피부 바깥으로 증발되지 못하게 하는 성분을 사용해야 한다(Chang et al., 2007; Kwon et al., 2013). 보습제의 조건은 안전성이 높 고, 안정성이 있어야 하며, 화장품으로 사용했을 때 발림성이 부 드럽고, 사용감이 좋아야 한다(Kang \& Hahm, 1996; Park, 2007).

본 연구에서 활용한 천연성분 Ectoin은 헤테로사이클릭 화합 물이자 아미노산 유도체이다. 소금호수, 온천, 영구 빙설 및 사 막과 같은 극한 환경에서 살고 있는 호염성 박테리아에서 추출된 성분으로 극한 조건에 적응하며 생존하는 천연 성분이다. Ectoin 은 극심한 온도 변화에 잘 견디고 성장했기에 유해한 환경으로 부터 신체를 보호한다. Ectoin은 천연 다기능 활성 성분으로 세 포보호나 가려움 방지, 피부 장벽 회복 등의 효능으로 인해 의약 품이나 여러 분야에서 다양하게 이용되고 있다(Galinski et al., 1985, Dirschka, 2008).

Ectoin은 피부의 면역 시스템을 유지하여 자외선과 냉기 및 외부의 해로운 환경으로부터 피부를 보호하며 수분을 형성하는 기능이 있어(Marini et al., 2014, Salapatek et al., 2011), 건 조하고 예민한 피부를 촉촉하게 가꾸어 주며, 피부결을 부드럽 고 유연하게 만들어 주어 최근에는 보습제 화장품의 원료로도 개발되고 있다(Bünger et al., 2010, Dwivedi et al., 2014; Heinrich et al., 2007).

삶의 질과 소득의 증가로 건강한 피부에 대한 관심과 천연 성 분에 대한 관심이 증가하고 있으며, 화장품 원료 시장은 잠재적 이고 무한한 성장가능성을 가진 산업분야로써, 이에 관한 꾸준한 연구와 개발이 이루어질 것이다.

본 연구에서는 천연 성분인 Ectoin을 활용하여 피부 보습에
관한 효과를 검증하고, 이에 따른 보습크림 화장품 소재로써의 효용성을 검증하고자 하였다.

\section{Methods}

\section{1. 연구 설계}

본 연구를 위해 20-40대 여성으로, 대조군(control group, C)과 실험군(experimental group, E)은 각 10명으로 구성하였 다. 연구대상자 제외 기준에 해당하는 경우는 연구대상에서 제외 하였으며, 임상 집단의 결과에 대한 변이를 최소화하기 위해 무 작위로 군집을 분류하였다. 연구대상자들에게는 인체 적용시험 과 관련된 모든 정보와 취지를 충분히 알렸으며, 연구 대상자는 자발적 의사에 따라 동의서를 작성하고 시험에 참가하였다. 임상 시험을 진행하면서 연구대상자 중 1 명이 중도 탈락하여, 대조군 9 명, 실험군 10 명의 데이터를 통계분석에 활용하였다.

\section{2. 연구 장소}

Kim et al. (2018)의 연구에 의하면 안면에 피부 측정에 있 어 피부 표면 온도와 색광도, TEWL과 유분을 모두 측정하고 자 할 때, $30 \mathrm{~min}$ 이상의 안정화가 필요하다는 연구결과를 보 고한 바 있다. 이에 따라 본 연구의 측정 및 진행은 온도 $22 \pm$ $1{ }^{\circ} \mathrm{C}$, 습도 $45 \pm 5 \%$ 의 항온 항습 상태의 실내 공간에서 동일한 세안제로 사용해 세안 후 최소 $30 \mathrm{~min}$ 피부의 안정을 취하고 측정 부위를 노출하여 측정하였다. 본 실험은 기관생명윤리위 원회(Institutional Review Board, IRB)에 심사-승인 후 2018 년 5월 25일부터 2018년 6월 25일까지 진행되었으며 제품 사 용 사전(0주), 사용 후 4 주차에 각각 측정하였다(승인번호: 7001355-201805-HR-244).

\section{3. 연구 도포 부위}

피부측정을 시행할 연구부위는 정확한 측정을 위해 땀이 적 게 나고 외부의 영향을 덜 받는 부위로 선정하였으며, 유분, 수 분, 경피수분손실량(transepidermal water loss, TEWL), $\mathrm{pH}$ 의 측정은 뺨(콧망울 옆 $2 \mathrm{~cm}$ ), 이마(미간 정중앙에서 위로 2 $\mathrm{cm}$ ), 턱(아랫입술 밑에서 $1.5 \mathrm{~cm}$ ) 부위를 3 회씩 측정 후 평균 값을 도출하였다. 멜라닌과 홍반 측정은 기미, 주근깨 등의 과 색소 침착 또는 모세혈관 확장으로 인한 안면 붉음증이 주로 나 타나는 좌우 관골 상부 외측으로 선정하였으며 같은 부위에 3 회 반복 측정 후 평균값을 도출하였다. 모공측정은 안면 전체를 촬영한 후, 이마, 코, 좌우 볼에 도출되는 값을 활용하였다.

\section{4. 연구 재료}

본 연구에서 사용된 Ectoin은 bitop (Germany)에서 구입하 
여 사용하였다. 본 실험에서 사용된 화장품은 클렌징폼, 토너, 크림, 로션 4가지로 Ectoin $1 \%$ 를 함유하여 제조하였고 Ectoin 분말 추출 시료는 백색 결정 분말 형태로 되어 있어, $80^{\circ} \mathrm{C}$ 로 가온하여 완전히 용해시킨 후 호모믹서(homo mixer, HM$\mathrm{U} 1.0$; JPL, Korea) 3,500 rpm으로 $10 \mathrm{~min}$ 동안 교반하였고, $28^{\circ} \mathrm{C}$ 까지 냉각하여 실온에서 보관하였다. 실험군은 Ectoin $1 \%$ 가 함유된 4 가지 시료를 지급하였고, 대조군은 Ectoin $1 \%$ 가 함 유되지 않은 4 가지 시료를 지급해 매일 아침, 저녁으로 2 회씩 4 주간 안면에 사용하도록 하였다.

\section{5. 연구 장비}

Skin pH meter (CORNEOMETER, SEBUMETER, SKIN-pH-METER; Cosmomed, Germany)는 피부의 유분, 수분, $\mathrm{pH}$ 를 측정하는 기기로, 외부환경에 노출되어 있는 피 부의 생리특성을 정확하게 반영한다. 본 연구에서는 skin $\mathrm{pH}$ meter를 활용하여 안면 피부의 유분, 수분, $\mathrm{pH}$ 를 측정하였다. DSM II Color Meter (Cortex technology, Denmark)는 피 부 색 측정기로 좌우 관골 상부 외측의 명도, 황색도, 적색도를 측정하는 기기이다. 본 연구에서는 DSM II Color Meter를 활 용하여 안면 피부의 멜라닌(melanin)과 홍반(erythema)을 측 정하였다. Derma Lab (DermaLab ${ }^{\circledR}$ USB test system with TEWL probe, Cortex technology)은 TEWL를 측정하는 기기 로, 본 연구에서는 Derma Lab을 활용하여 안면 피부의 TEWL 을 측정하였다. Janus (JANUS I ; PIE, Korea)는 광원으로 플래쉬를 사용하며 일반광, 편광, 자외선광에서 촬영된 세 가지 의 이미지를 화면상에서 볼 수 있고, 각 광원에서 확인할 수 있 는 안면 피부의 모공, 주름, 색소침착, 피지, 피부 밝기를 분석 한다. 본 연구에서는 Janus를 활용하여 안면 피부의 모공을 측 정하였다.

\section{6. 통계 처리}

본 연구를 통해 수집된 자료의 분석은 통계프로그램 SPSS 24.0 for Windows (IBM, USA)를 이용하여 분석하였다. 연구 대상자의 실험 전 집단 간 동질성 검증을 위해 독립표본 $t$-test 를, 사전과 사후 유분, 수분, TEWL, 모공, $\mathrm{pH}$, 피부색의 변화 를 분석하기 위해 대응표본 $t$-test를 시행하였다.

\section{Results and Discussion}

\section{1. 연구대상자의 일반적 특성}

본 연구대상자의 사전 안면 피부상태는 Table 1 과 같다. C와 $\mathrm{E}$ 의 사전 안면 피부상태 분석을 위한 유분, 수분, TEWL, 모공, $\mathrm{pH}$, 멜라닌과 홍반 모든 항목에서 집단 간 유의한 차이를 나타
내지 않았다 $(p>0.05)$. 따라서 실험군과 대조군의 사전 안면 피 부상태 동질성이 확보되었다.

\section{2. 유분의 변화}

대조군과 실험군의 유분 변화는 Table 2 와 같다. 이마에서 대 조군은 이마에서 사전 30.77 (mean, M)에서 사후 31.77 (M) 로, $3.24 \%$ 유분이 증가했으며, 실험군은 사전 $36.20(\mathrm{M})$ 에서 사후 $26.50(\mathrm{M})$ 으로 $26.79 \%$ 유분이 감소했고, 턱에서 대조군 은 사전 $32.77(\mathrm{M})$ 에서 사후 $35.55(\mathrm{M})$ 로 $8.45 \%$ 유분이 증 가했으며, 실험군은 사전 $29.40(\mathrm{M})$ 에서 사후 $28.60(\mathrm{M})$ 으로 $2.72 \%$ 유분이 감소했다. 오른쪽 볼에서 대조군은 사전 13.66 (M)에서 사후 $14.77(\mathrm{M})$ 로 $8.12 \%$, 실험군은 사전 $16.40(\mathrm{M})$ 에서 사후 $19.70(\mathrm{M})$ 으로 $20.12 \%$ 로 모두 유분이 증가했고, 왼쪽 볼에서 대조군은 사전 $12.44(\mathrm{M})$ 에서 사후 $17.44(\mathrm{M})$ 로 $40.19 \%$, 실험군은 사전 $20.30(\mathrm{M})$ 에서 사후 $20.60(\mathrm{M})$ 으로 $1.47 \%$ 로 모두 유분이 증가했다.

모든 항목에서 유의한 변화는 없었지만, 대조군의 경우 $\mathrm{T}$ 존 과 $\mathrm{U}$ 존 모두에서 유분의 증가를 나타냈고, 실험군의 경우 $\mathrm{T}$ 존 에서는 유분의 감소를 보이며 이마와 턱에서 사후 각각 26.50 $(\mathrm{M})$ 과 $28.60(\mathrm{M})$ 을, $\mathrm{U}$ 존에서는 유분의 증가를 보이며 오른쪽 볼과 왼쪽 볼에서는 사후 각각 $19.70(\mathrm{M})$ 과 $20.60(\mathrm{M})$ 을 나타 냈다. 따라서 실험군의 시료에만 함유된 Ectoin이 T존과 U존 의 피지 균형에 기여하는 것으로 추정된다.

\section{3. 수분의 변화}

대조군과 실험군의 수분 변화는 Table 3 과 같다. 이마에서 대 조군은 사전 $64.90(\mathrm{M})$ 에서 사후 $69.12(\mathrm{M})$ 로 $6.48 \%$ 수분이 증가했으며, 실험군은 사전 $61.07(\mathrm{M})$ 에서 사후 $67.43(\mathrm{M})$ 으 로 $10.39 \%$ 로 수분의 증가가 유의하게 보였다 $(p<0.01)$. 턱에서 대조군은 사전 $62.96(\mathrm{M})$ 에서 사후 $64.82(\mathrm{M})$ 로 $2.94 \%$, 실험 군은 사전 $63.28(\mathrm{M})$ 에서 사후 $69.03(\mathrm{M})$ 으로 $9.08 \%$ 로 모두 수분이 증가했다. 오른쪽 볼에서 대조군은 사전 $70.98(\mathrm{M})$ 에서 사후 $74.19(\mathrm{M})$ 로 $2.78 \%$ 수분이 증가했으며, 실험군은 사전 $69.37(\mathrm{M})$ 에서 사후 $74.91(\mathrm{M})$ 로 $7.98 \%$ 수분이 증가하여 유 의한 수분의 증가를 보였고 $(p<0.05)$, 왼쪽 볼에서 대조군은 사 전 $72.51(\mathrm{M})$ 에서 사후 $74.35(\mathrm{M})$ 로 $2.53 \%$ 로 수분이 증가했 으며, 실험군은 사전 $69.71(\mathrm{M})$ 에서 사후 $76.11(\mathrm{M})$ 로 $9.18 \%$ 수분이 증가하여 유의한 수분의 증가를 보였다 $(p<0.01)$.

대조군과 실험군 모두 사후 수분이 증가했지만, 모든 항목에 서 대조군보다 실험군의 수분함유량 증가가 크게 나타났으며, 실험군은 턱을 제외한 모든 항목에서 수분의 유의한 증가를 나 타냈다. 따라서 실험군의 시료에만 함유된 Ectoin이 피부의 수 분함유량을 유의하게 증가시키는 것으로 판단된다. 
Table 1. Verification of homogeneity between $C$ and $E$ group

\begin{tabular}{|c|c|c|c|c|c|c|}
\hline Variables & & & $\begin{array}{l}C(n=9) \\
M \pm S D\end{array}$ & $\begin{array}{c}E(n=10) \\
M \pm S D\end{array}$ & $t$ & $p$ \\
\hline \multirow{4}{*}{ Sebum } & \multicolumn{2}{|l|}{ Forehead } & $30.77 \pm 14.82$ & $36.20 \pm 17.95$ & -0.713 & 0.486 \\
\hline & \multicolumn{2}{|l|}{ Jew } & $32.77 \pm 18.41$ & $29.40 \pm 18.71$ & 0.396 & 0.697 \\
\hline & \multicolumn{2}{|l|}{ Rt. cheek } & $13.66 \pm 6.51$ & $16.40 \pm 10.57$ & -0.668 & 0.513 \\
\hline & \multicolumn{2}{|l|}{ Lt. cheek } & $12.44 \pm 8.74$ & $20.30 \pm 15.83$ & -1.356 & 0.196 \\
\hline \multirow{4}{*}{ Moisture } & \multicolumn{2}{|l|}{ Forehead } & $64.90 \pm 8.05$ & $61.07 \pm 6.58$ & 1.138 & 0.271 \\
\hline & \multicolumn{2}{|l|}{ Jew } & $62.96 \pm 5.85$ & $63.28 \pm 7.43$ & -0.103 & 0.920 \\
\hline & \multicolumn{2}{|l|}{ Rt. cheek } & $70.98 \pm 6.34$ & $69.37 \pm 7.20$ & 0.517 & 0.612 \\
\hline & \multicolumn{2}{|l|}{ Lt. cheek } & $72.51 \pm 7.86$ & $69.71 \pm 6.28$ & 0.863 & 0.400 \\
\hline \multirow{4}{*}{ TEWL } & \multicolumn{2}{|l|}{ Forehead } & $11.40 \pm 4.52$ & $19.32 \pm 13.44$ & -1.756 & 0.106 \\
\hline & \multicolumn{2}{|l|}{ Jew } & $15.97 \pm 13.12$ & $14.94 \pm 6.98$ & 0.218 & 0.830 \\
\hline & \multicolumn{2}{|l|}{ Rt. cheek } & $10.32 \pm 2.15$ & $11.52 \pm 1.87$ & -1.297 & 0.212 \\
\hline & \multicolumn{2}{|l|}{ Lt. cheek } & $10.73 \pm 3.25$ & $15.60 \pm 6.41$ & -2.047 & 0.056 \\
\hline \multirow{4}{*}{ Pore } & \multicolumn{2}{|l|}{ Forehead } & $36.22 \pm 9.01$ & $39.00 \pm 12.62$ & -0.546 & 0.592 \\
\hline & \multicolumn{2}{|l|}{ Nose } & $19.55 \pm 8.01$ & $24.30 \pm 12.36$ & -0.979 & 0.341 \\
\hline & \multicolumn{2}{|l|}{ Rt. cheek } & $22.00 \pm 10.60$ & $22.10 \pm 11.03$ & -0.020 & 0.984 \\
\hline & \multicolumn{2}{|l|}{ Lt. cheek } & $27.77 \pm 13.22$ & $26.70 \pm 13.49$ & 0.175 & 0.863 \\
\hline \multirow{4}{*}{$\mathrm{pH}$} & \multicolumn{2}{|l|}{ Forehead } & $5.86 \pm 0.19$ & $5.75 \pm 0.41$ & 0.752 & 0.462 \\
\hline & \multicolumn{2}{|l|}{ Jew } & $5.92 \pm 0.23$ & $5.89 \pm 0.24$ & 0.343 & 0.736 \\
\hline & \multicolumn{2}{|l|}{ Rt. cheek } & $5.92 \pm 0.28$ & $5.89 \pm 0.23$ & 0.287 & 0.777 \\
\hline & \multicolumn{2}{|l|}{ Lt. cheek } & $5.86 \pm 0.38$ & $5.93 \pm 0.19$ & -0.516 & 0.612 \\
\hline \multirow{4}{*}{ Skin color value } & \multirow{2}{*}{ Rt. lid cheek } & Melanin & $27.24 \pm 1.60$ & $29.46 \pm 3.40$ & -1.780 & 0.093 \\
\hline & & Erythema & $12.92 \pm 1.31$ & $14.64 \pm 2.70$ & -1.786 & 0.097 \\
\hline & \multirow{2}{*}{ Lt. lid cheek } & Melanin & $27.40 \pm 2.58$ & $29.21 \pm 3.42$ & -1.286 & 0.216 \\
\hline & & Erythema & $12.41 \pm 4.58$ & $15.78 \pm 3.78$ & -1.736 & 0.102 \\
\hline
\end{tabular}

C, control group; E, experimental group; M, mean; SD, standard deviation; Rt., right; Lt., left.

Table 2. Comparison of facial sebum

(Unit: $\mu \mathrm{g} / \mathrm{cm}^{2}$ )

\begin{tabular}{|c|c|c|c|c|c|c|}
\hline \multirow[t]{2}{*}{ Variables } & \multirow[t]{2}{*}{ Group } & \multicolumn{2}{|c|}{$\begin{array}{l}\text { Measurement } \\
(\mathrm{M} \pm \mathrm{SD})\end{array}$} & \multirow[t]{2}{*}{$t_{1}-t_{2}$} & \multirow{2}{*}{\multicolumn{2}{|c|}{$t(p)$}} \\
\hline & & Before & After & & & \\
\hline \multirow{2}{*}{ Forehead } & $C(n=9)$ & $30.77 \pm 14.82$ & $31.77 \pm 16.33$ & $-1.00 \pm 9.55$ & -0.314 & $(0.762)$ \\
\hline & $E(n=10)$ & $36.20 \pm 17.95$ & $26.50 \pm 18.10$ & $9.70 \pm 4.85$ & 1.998 & $(0.077)$ \\
\hline \multirow{2}{*}{ Jew } & $C(n=9)$ & $32.77 \pm 18.41$ & $35.55 \pm 21.15$ & $-2.77 \pm 7.64$ & -1.090 & (0.307) \\
\hline & $E(n=10)$ & $29.40 \pm 18.71$ & $28.60 \pm 17.53$ & $0.80 \pm 12.52$ & 0.202 & $(0.844)$ \\
\hline \multirow{2}{*}{ Rt. cheek } & $C(n=9)$ & $13.66 \pm 6.51$ & $14.77 \pm 8.16$ & $-1.11 \pm 7.21$ & -0.462 & (0.657) \\
\hline & $E(n=10)$ & $16.40 \pm 10.57$ & $19.70 \pm 18.03$ & $-3.30 \pm 12.17$ & -0.857 & $(0.414)$ \\
\hline \multirow{2}{*}{ Lt. cheek } & $C(n=9)$ & $12.44 \pm 8.74$ & $17.44 \pm 12.69$ & $-5.00 \pm 8.54$ & -1.756 & $(0.117)$ \\
\hline & $E(n=10)$ & $20.30 \pm 15.83$ & $20.60 \pm 13.46$ & $-0.30 \pm 11.19$ & -0.085 & $(0.934)$ \\
\hline
\end{tabular}

C, control group; E, experimental group; M, mean; SD, standard deviation; Rt., right; Lt., left; $t_{1}$, before; $t_{2}$, after.

Table 3. Comparison of facial moisture

(Unit: AU)

\begin{tabular}{|c|c|c|c|c|c|c|}
\hline \multirow[t]{2}{*}{ Variable } & \multirow[t]{2}{*}{ Group } & \multicolumn{2}{|c|}{$\begin{array}{l}\text { Measurement } \\
(\mathrm{M} \pm \mathrm{SD})\end{array}$} & \multirow{2}{*}{$t_{1}-t_{2}$} & \multirow{2}{*}{\multicolumn{2}{|c|}{$t(p)$}} \\
\hline & & Before & After & & & \\
\hline \multirow{2}{*}{ Forehead } & $C(n=9)$ & $64.90 \pm 8.05$ & $69.12 \pm 6.78$ & $-4.21 \pm 6.46$ & -1.956 & $(0.086)$ \\
\hline & $E(n=10)$ & $61.07 \pm 6.58$ & $67.43 \pm 6.34$ & $-6.35 \pm 5.85$ & -3.432 & $\left(0.007^{* *}\right)$ \\
\hline \multirow{2}{*}{ Jew } & $C(n=9)$ & $62.96 \pm 5.85$ & $64.82 \pm 5.74$ & $-1.86 \pm 5.56$ & -1.003 & $(0.345)$ \\
\hline & $E(n=10)$ & $63.28 \pm 7.43$ & $69.03 \pm 7.51$ & $-5.75 \pm 10.80$ & -1.683 & $(0.127)$ \\
\hline \multirow{2}{*}{ Rt. cheek } & $C(n=9)$ & $70.98 \pm 6.34$ & $74.19 \pm 3.57$ & $-3.205 \pm 4.85$ & -1.985 & $(0.082)$ \\
\hline & $E(n=10)$ & $69.37 \pm 7.20$ & $74.91 \pm 5.32$ & $-5.54 \pm 6.85$ & -2.557 & $\left(0.031^{*}\right)$ \\
\hline \multirow{2}{*}{ Lt. cheek } & $C(n=9)$ & $72.51 \pm 7.86$ & $74.35 \pm 5.63$ & $-1.845 \pm 5.95$ & -0.929 & $(0.380)$ \\
\hline & $E(n=10)$ & $69.71 \pm 6.28$ & $76.11 \pm 4.58$ & $-6.40 \pm 6.12$ & -3.309 & $\left(0.009^{* *}\right)$ \\
\hline
\end{tabular}

C, control group; E, experimental group; $M$, mean; SD, standard deviation; Rt., right; Lt., left; $\mathrm{t}_{1}$, before; $\mathrm{t}_{2}$, after. ${ }^{*} p<0.05 ;{ }^{* *} p<0.01$. 


\section{TEWL의 변화}

대조군과 실험군의 TEWL 변화는 Table 4 와 같다. 이마에서 대조군은 사전 $11.40(\mathrm{M})$ 에서 사후 $13.20(\mathrm{M})$ 으로 TEWL이 $15.78 \%$ 로 유의하게 증가했으며 $(p<0.01)$, 실험군은 사전 19.32 (M)에서 사후 $14.93(\mathrm{M})$ 으로 TEWL이 $22.72 \%$ 감소했다. 턱에 서 대조군은 사전 $15.97(\mathrm{M})$ 에서 사후 $11.16(\mathrm{M})$ 으로 $30.11 \%$, 실험군은 사전 $14.94(\mathrm{M})$ 에서 사후 $13.37(\mathrm{M})$ 으로 $25.77 \%$ 가 TEWL이 모두 감소했다. 오른쪽 볼에서 대조군은 사전 10.32 $(\mathrm{M})$ 에서 사후 $12.98(\mathrm{M})$ 로 $25.77 \%$ 로 TEWL이 증가했으며, 실험군은 사전 $11.52(\mathrm{M})$ 에서 사후 $8.45(\mathrm{M})$ 으로 TEWL이 $26.64 \%$ 로 유의하게 감소했다 $(p<0.05)$. 왼쪽 볼에서 대조군 은 사전 $10.73(\mathrm{M})$ 에서 사후 $11.50(\mathrm{M})$ 으로 TEWL이 $7.08 \%$ 증가했으며, 실험군은 사전 $15.60(\mathrm{M})$ 에서 사후 $11.77(\mathrm{M})$ 로 TEWL이 $24.55 \%$ 로 감소했다.

대조군은 이마, 오른쪽 볼과 왼쪽 볼에서 TEWL이 증가했고, 실험군은 모든 항목에서 TEWL의 감소를 나타냈다. 이는 앞서 제시한 Table 3의 수분함유량에서 실험군이 사전 대비 사후 모 든 항목에서 수분의 증가를 보인 것과 상통한다. 또한 Table 2 의 유분 변화에서 실험군은 사전 대비 사후 $\mathrm{T}$ 존과 $\mathrm{U}$ 존의 균형이 적 절하게 조정된 것을 확인할 수 있었고, 이러한 유분과 수분의 균
형이 결국 경피수분손실량을 감소시킨 것으로 판단된다.

\section{5. 모공의 변화}

대조군과 실험군의 모공 변화는 Table 5 와 같다. 이마에서 대 조군은 사전 $36.22(\mathrm{M})$ 에서 사후 $34.66(\mathrm{M})$ 으로 $4.27 \%$ 모공 이 감소했으며, 실험군은 사전 $39.00(\mathrm{M})$ 에서 사후 $35.80(\mathrm{M})$ 으로 유의하게 $8.20 \%$ 가 감소했다 $(p<0.05)$. 코에서 대조군은 사 전 $19.55(\mathrm{M})$ 에서 사후 $18.66(\mathrm{M})$ 으로 $4.50 \%$ 모공이 감소했 으며, 실험군은 사전 $24.30(\mathrm{M})$ 에서 사후 $22.40(\mathrm{M})$ 으로 유의 하게 $7.81 \%$ 가 감소했다 $(p<0.05)$. 오른쪽 볼에서 대조군은 사 전 $22.00(\mathrm{M})$ 에서 사후 $22.11(\mathrm{M})$ 로 모공이 $0.5 \%$ 가 증가했으 며, 실험군은 사전 $22.10(\mathrm{M})$ 에서 사후 $21.30(\mathrm{M})$ 으로 모공이 $3.61 \%$ 로 감소했다. 왼쪽 볼에서 대조군은 사전 $27.77(\mathrm{M})$ 에서 사후 $27.33(\mathrm{M})$ 으로 $1.58 \%$, 실험군은 사전 $26.70(\mathrm{M})$ 에서 사 후 $24.30(\mathrm{M})$ 으로 모공이 $8.98 \%$ 가 감소했다.

대조군에서는 모공의 증가와 감소가 교차하는 경향을 나타냈 지만, 실험군에서는 모든 항목에서 모공의 감소를 나타냈다.

\section{6. $\mathrm{pH}$ 의 변화}

대조군과 실험군의 $\mathrm{pH}$ 변화는 Table 6 과 같다. 이마에서 대조

Table 4. Comparison of facial TEWL

(Unit: AU)

\begin{tabular}{|c|c|c|c|c|c|c|}
\hline \multirow[t]{2}{*}{ Variable } & \multirow[t]{2}{*}{ Group } & \multicolumn{2}{|c|}{$\begin{array}{l}\text { Measurement } \\
(\mathrm{M} \pm \mathrm{SD})\end{array}$} & \multirow{2}{*}{$t_{1}-t_{2}$} & \multirow{2}{*}{\multicolumn{2}{|c|}{$t(p)$}} \\
\hline & & Before & After & & & \\
\hline \multirow{2}{*}{ Forehead } & $C(n=9)$ & $11.40 \pm 4.52$ & $13.20 \pm 4.62$ & $-1.80 \pm 1.48$ & -3.628 & $\left(0.007^{* *}\right)$ \\
\hline & $E(n=10)$ & $19.32 \pm 13.44$ & $14.93 \pm 9.41$ & $4.39 \pm 6.13$ & 2.263 & $(0.050)$ \\
\hline \multirow{2}{*}{ Jew } & $C(n=9)$ & $15.97 \pm 13.12$ & $11.16 \pm 3.27$ & $4.81 \pm 13.16$ & 1.096 & $(0.305)$ \\
\hline & $E(n=10)$ & $14.94 \pm 6.98$ & $13.37 \pm 4.79$ & $1.57 \pm 3.78$ & 1.310 & $(0.223)$ \\
\hline \multirow{2}{*}{ Rt. cheek } & $C(n=9)$ & $10.32 \pm 2.15$ & $12.98 \pm 4.39$ & $-2.66 \pm 4.63$ & -1.726 & $(0.123)$ \\
\hline & $E(n=10)$ & $11.52 \pm 1.87$ & $8.45 \pm 2.25$ & $3.07 \pm 3.34$ & 2.901 & $\left(0.018^{*}\right)$ \\
\hline \multirow{2}{*}{ Lt. cheek } & $C(n=9)$ & $10.73 \pm 3.25$ & $11.50 \pm 3.59$ & $-0.76 \pm 3.46$ & -0.663 & $(0.526)$ \\
\hline & $E(n=10)$ & $15.60 \pm 6.41$ & $11.77 \pm 3.84$ & $3.83 \pm 6.34$ & 1.909 & $(0.089)$ \\
\hline
\end{tabular}

TEWL, transepidermal water loss; C, control group; $E$, experimental group; $M$, mean; SD, standard deviation; Rt., right; Lt., left; $t_{1}$, before; $t_{2}$, after.

${ }^{*} p<0.05 ;{ }^{* *} p<0.01$.

Table 5. Comparison of facial pore

\begin{tabular}{|c|c|c|c|c|c|c|}
\hline \multirow[t]{2}{*}{ Variable } & \multirow[t]{2}{*}{ Group } & \multicolumn{2}{|c|}{$\begin{array}{c}\text { Measurement } \\
(\mathrm{M} \pm \mathrm{SD})\end{array}$} & \multirow[t]{2}{*}{$t_{1}-t_{2}$} & \multirow{2}{*}{\multicolumn{2}{|c|}{$t(p)$}} \\
\hline & & Before & After & & & \\
\hline \multirow{2}{*}{ Forehead } & $C(n=9)$ & $36.22 \pm 9.01$ & $34.66 \pm 7.17$ & $1.55 \pm 5.68$ & 0.821 & $(0.435)$ \\
\hline & $E(n=10)$ & $39.00 \pm 12.62$ & $35.80 \pm 12.76$ & $3.20 \pm 4.39$ & 2.304 & $\left(0.047^{*}\right)$ \\
\hline \multirow{2}{*}{ Nose } & $C(n=9)$ & $19.55 \pm 8.01$ & $18.66 \pm 7.38$ & $0.88 \pm 3.10$ & 0.860 & $(0.415)$ \\
\hline & $E(n=10)$ & $24.30 \pm 12.36$ & $22.40 \pm 12.42$ & $1.90 \pm 2.28$ & 2.632 & $\left(0.027^{*}\right)$ \\
\hline \multirow{2}{*}{ Rt. cheek } & $C(n=9)$ & $22.00 \pm 10.60$ & $22.11 \pm 10.71$ & $-0.11 \pm 2.42$ & -0.138 & $(0.894)$ \\
\hline & $E(n=10)$ & $22.10 \pm 11.03$ & $21.30 \pm 10.85$ & $0.80 \pm 2.93$ & 0.862 & $(0.411)$ \\
\hline \multirow{2}{*}{ Lt. cheek } & $C(n=9)$ & $27.77 \pm 13.22$ & $27.33 \pm 13.89$ & $0.44 \pm 2.60$ & 0.512 & $(0.622)$ \\
\hline & $E(n=10)$ & $26.70 \pm 13.49$ & $24.30 \pm 12.50$ & $2.40 \pm 4.40$ & 1.724 & $(0.119)$ \\
\hline
\end{tabular}

C, control group; E, experimental group; $M$, mean; SD, standard deviation; Rt., right; Lt., left; $\mathrm{t}_{1}$, before; $\mathrm{t}_{2}$, after. ${ }^{*} p<0.05$. 
군은 사전 $5.86(\mathrm{M})$ 에서 사후 $5.73(\mathrm{M})$ 으로 $\mathrm{pH}$ 가 $2.21 \%$ 감소 를, 실험군은 사전 $5.75(\mathrm{M})$ 에서 사후 $5.77(\mathrm{M})$ 로 $\mathrm{pH}$ 가 $0.17 \%$ 증가를 보였으며, 턱에서 대조군은 사전 $5.92(\mathrm{M})$ 에서 사후 $5.87(\mathrm{M})$ 로 $0.84 \%$, 실험군은 사전 $5.89(\mathrm{M})$ 에서 사후 $5.80(\mathrm{M})$ 으로 $1.35 \%$ 로 모두 $\mathrm{pH}$ 의 감소를 보였다. 오른쪽 볼에서 대조군 은 사전 $5.92(\mathrm{M})$ 에서 사후 $5.87(\mathrm{M})$ 로 $0.84 \%$, 실험군은 사전 $5.89(\mathrm{M})$ 에서 사후 $5.88(\mathrm{M})$ 로 $0.16 \%$ 로 $\mathrm{pH}$ 가 모두 감소했으 며, 왼쪽 볼에서 대조군은 사전 $5.86(\mathrm{M})$ 에서 사후 $5.88(\mathrm{M})$ 로 $0.34 \%$ 증가를, 실험군은 사전 $5.93(\mathrm{M})$ 에서 사후 $5.81(\mathrm{M})$ 로 $\mathrm{pH}$ 가 $0.33 \%$ 감소했다.

사전·사후 모든 $\mathrm{pH}$ 는 평균 4.5-6.5에 해당하는 피부의 정상 $\mathrm{pH}$ 범주를 보였으며, 유의한 변화는 나타나지 않았다. 본 연구 의 모든 대상자는 건강한 피부상태를 가지고 있는 대상자로 선 별되었고, 사전·사후 대조군과 실험군 모두에서 유의한 $\mathrm{pH}$ 의 변 화가 없었다는 것은 실험군의 시료에만 함유시킨 Ectoin이 피부 $\mathrm{pH}$ 의 변화를 유발하거나 자극요인으로 작용하지 않는다는 것을 반증하는 결과라는 점에서 Table 6 은 의미 있는 결과로 해석된 다.

\section{7. 피부색의 변화}

대조군과 실험군의 피부색 변화는 Table 7과 같다. 우측 관골
상부에서 대조군의 멜라닌은 사전 27.24 (M)에서 사후 27.29 (M)로 $0.18 \%$ 증가했으며, 실험군은 사전 $29.46(\mathrm{M})$ 에서 사후 $27.93(\mathrm{M})$ 으로 멜라닌이 $5.15 \%$ 가 유의하게 감소했다 $(p<0.01)$. 좌측 관골 상부에서 대조군의 멜라닌은 사전 $27.40(\mathrm{M})$ 에서 사 후 $27.37(\mathrm{M})$ 로 $11.31 \%$ 가 유의하게 감소했으며 $(p<0.001)$, 실 험군은 사전 $29.21(\mathrm{M})$ 에서 사후 $28.85(\mathrm{M})$ 로 $12.29 \%$ 로 멜 라닌이 유의하게 감소했다 $(p<0.001)$. 우측 관골 상부에서 대조 군의 홍반은 사전 $12.92(\mathrm{M})$ 에서 사후 $9.82(\mathrm{M})$ 로 $0.23 \%$, 실 험군은 사전 $14.64(\mathrm{M})$ 에서 사후 $11.05(\mathrm{M})$ 으로 $2.39 \%$ 로 홍 반이 모두 감소했고, 좌측 관골 상부에서 대조군의 홍반은 사전 $12.41(\mathrm{M})$ 에서 사후 $10.31(\mathrm{M})$ 로 $16.84 \%$ 가 감소했으며, 실험 군은 사전 $15.78(\mathrm{M})$ 에서 사후 $11.69(\mathrm{M})$ 로 $25.91 \%$ 가 유의하 게 감소했다 $(p<0.01)$.

대조군의 멜라닌은 증가와 감소가 교차하는 반면, 실험군의 멜 라닌은 좌우 모두에서 유의한 감소를 나타냈고, 홍반은 대조군과 실험군에서 모두 감소를 나타냈으나, 실험군의 홍반이 대조군에 비해 크게 감소한 결과는 보였다.

앞서 기술한 바와 같이, 피부세포의 수분함유량이 증가함으로 써 각 세포의 물리적 부피가 증가했고, 이로 인해 기저층의 멜 라닌 세포와 진피의 모세혈관으로부터 각질층과의 물리적 거리 가 증가했을 것으로 판단된다. 피부의 적색도는 헤모글로빈 양과

Table 6. Comparison of facial pH

\begin{tabular}{|c|c|c|c|c|c|c|}
\hline \multirow[t]{2}{*}{ Variable } & \multirow[t]{2}{*}{ Group } & \multicolumn{2}{|c|}{$\begin{array}{l}\text { Measurement } \\
(\mathrm{M} \pm \mathrm{SD})\end{array}$} & \multirow{2}{*}{$t_{1}-t_{2}$} & \multirow{2}{*}{\multicolumn{2}{|c|}{$t(p)$}} \\
\hline & & Before & After & & & \\
\hline \multirow{2}{*}{ Forehead } & $C(n=9)$ & $5.86 \pm 0.19$ & $5.73 \pm 0.21$ & $0.13 \pm 0.20$ & 1.993 & $(0.081)$ \\
\hline & $E(n=10)$ & $5.75 \pm 0.41$ & $5.77 \pm 0.26$ & $-0.01 \pm 0.37$ & -0.145 & $(0.888)$ \\
\hline \multirow{2}{*}{ Jew } & $C(n=9)$ & $5.92 \pm 0.23$ & $5.87 \pm 0.13$ & $0.05 \pm 0.22$ & 0.666 & $(0.524)$ \\
\hline & $E(n=10)$ & $5.89 \pm 0.24$ & $5.80 \pm 0.23$ & $0.08 \pm 0.25$ & 1.057 & (0.318) \\
\hline \multirow{2}{*}{ Rt. cheek } & $C(n=9)$ & $5.92 \pm 0.28$ & $5.87 \pm 0.14$ & $0.05 \pm 0.25$ & 0.638 & $(0.541)$ \\
\hline & $E(n=10)$ & $5.89 \pm 0.23$ & $5.88 \pm 0.16$ & $0.01 \pm 0.19$ & 0.174 & $(0.866)$ \\
\hline \multirow{2}{*}{ Lt. cheek } & $C(n=9)$ & $5.86 \pm 0.38$ & $5.88 \pm 0.15$ & $-0.02 \pm 0.28$ & -0.238 & $(0.818)$ \\
\hline & $E(n=10)$ & $5.93 \pm 0.19$ & $5.81 \pm 0.11$ & $0.11 \pm 0.24$ & 1.515 & $(0.164)$ \\
\hline
\end{tabular}

C, control group; E, experimental group; M, mean; SD, standard deviation; Rt., right; Lt., left; t1, before; t2, after.

Table 7. Comparison of facial skin color value

\begin{tabular}{|c|c|c|c|c|c|c|c|}
\hline \multirow[t]{2}{*}{ Variable } & & \multirow[t]{2}{*}{ Group } & \multicolumn{2}{|c|}{$\begin{array}{c}\text { Measurement } \\
(\mathrm{M} \pm \mathrm{SD})\end{array}$} & \multirow[t]{2}{*}{$t_{1}-t_{2}$} & \multirow{2}{*}{\multicolumn{2}{|c|}{$t(p)$}} \\
\hline & & & Before & After & & & \\
\hline \multirow{4}{*}{$\begin{array}{l}\text { Rt. lid } \\
\text { cheek }\end{array}$} & \multirow{2}{*}{ Melanin } & $C(n=9)$ & $27.24 \pm 1.60$ & $27.29 \pm 1.37$ & $-0.05 \pm 1.06$ & -0.147 & $(0.887)$ \\
\hline & & $E(n=10)$ & $29.46 \pm 3.40$ & $27.93 \pm 3.51$ & $1.52 \pm 1.42$ & 3.384 & $\left(0.008^{* *}\right)$ \\
\hline & \multirow{2}{*}{ Erythema } & $C(n=9)$ & $12.92 \pm 1.31$ & $9.82 \pm 1.43$ & $0.03 \pm 0.88$ & 0.100 & $(0.923)$ \\
\hline & & $E(n=10)$ & $14.64 \pm 2.70$ & $11.05 \pm 2.91$ & $0.35 \pm 1.66$ & 0.683 & $(0.512)$ \\
\hline \multirow{4}{*}{$\begin{array}{l}\text { Lt. lid } \\
\text { cheek }\end{array}$} & \multirow{2}{*}{ Melanin } & $C(n=9)$ & $27.40 \pm 2.58$ & $27.37 \pm 1.83$ & $3.10 \pm 1.14$ & 8.143 & $\left(0.000^{* * *}\right)$ \\
\hline & & $E(n=10)$ & $29.21 \pm 3.42$ & $28.85 \pm 3.06$ & $3.59 \pm 1.94$ & 5.851 & $\left(0.000^{* * *}\right)$ \\
\hline & \multirow{2}{*}{ Erythema } & $C(n=9)$ & $12.41 \pm 4.58$ & $10.31 \pm 1.98$ & $2.09 \pm 3.98$ & 1.580 & $(0.153)$ \\
\hline & & $E(n=10)$ & $15.78 \pm 3.78$ & $11.69 \pm 2.34$ & $4.09 \pm 3.83$ & 3.377 & $\left(0.008^{* *}\right)$ \\
\hline
\end{tabular}

C, control group; $\mathrm{E}$, experimental group; $\mathrm{M}$, mean; $\mathrm{SD}$, standard deviation; Rt., right; Lt., left $\mathrm{t}_{1}$, before; $\mathrm{t}_{2}$, after.

${ }^{* *} p<0.01 ;{ }^{* * *} p<0.001$. 
피부 표면의 두께, 혈관의 두께, 외부 자극 등에 의해 영향을 받 는데(Yi et al., 1992), 안와 하부의 청색도는 지방 두께의 불균 형으로 인한 구조적인 문제거나 얇은 피부조직으로 인해 하부의 조직이나 혈관이 비춰 보이는 경우, 색소침착으로 인한 경우 등 여러 가지 증세로 복합적으로 보는 것이 타당하다(Shin et al., 2011).

Ectoin에 대한 미백 효용성 검증에 관한 연구는 아직 미비한 상황이다. 따라서 Ectoin이 미백 기능성으로 작용했다는 근거를 제시하기에는 무리가 있지만, 대조군에서 나타난 유의한 변화는 논리적으로 설명된다.

\section{Conclusion}

본 연구는 천연성분 Ectoin이 피부 수분 및 보습에 미치는 영 향을 보기 위해 Ectoin을 화장품으로 제조하여 실험군과 대조군 을 비교하여 연구를 진행하였다.

천연성분을 화장품으로 제조하여 피부 보습 및 수분에 미치는 영향에 대한 선행연구들은 많이 나와 있었다. 하지만 Ectoin으로 나온 선행논문들은 국내에서 미비하여 진행한 결과 피부 보습 및 수분에 긍정적인 효과를 미치는 것으로 사료된다.

Ectoin을 비교하여 피부 유분, 수분, TEWL, 모공, 피부색의 변화에 통계적인 유의한 차이가 나타나지 못한 것은 Ectoin 농도 가 조금 약한 것으로 사료된다. 성분에 대한 농도를 좀 더 늘리면 효과가 있을 것으로 사료된다.

본 연구의 실험결과에서 천연성분인 Ectoin이 함유된 크림이 피부 보습 및 수분에 미치는 긍정적인 영향을 객관화, 수치화하 였고, 다만, 주름, 미백 효용성 검증에 관한 연구가 미비한 상황 이기에 다른 기능들까지 포함하는 제형이 개발된다면 토탈 안티 에이징 제품으로서의 가치를 높일 수 있을 것이다. 이를 보완하 여 다른 천연 추출물들과 결합하여 화장품을 통해 다양한 긍정적 인 효과 증명에 대한 연구를 제언하며, 천연성분 Ectoin이 화장 품 원료로서 긍정적인 영향을 미칠 것을 기대해본다.

\section{References}

Boelsma E, Hendriks HF, Roza L. Nutritional skin care: health effects of micronutrients and fatty acids. The American Journal of Clinical Nutrition, 73: 853-864, 2001.

Bünger J, Degwert JDH. The protective function of compatible solute Ectoine on the skin cells and its biomolecules with respect to UV-radiation, immunosupression and membrane damage. IFSCC Magazine, 4: 1-6, 2010.
Chang MY, Kim JJ, Lee CK. Moisturizer in cosmetics: classification of moisturizers by action mechanism. The Journal of Skin Barrier Research, 9: 18-26, 2007.

Dirschka T. Ectoin: anwendung und perspektiven für die dermatologie. Aktuelle Dermatologie, 34: 115-118, 2008.

Dwivedi M, Backers H, Harishchandra RK, Galla HJ. Biophysical investigations of the structure and function of the tear fluid lipid layer and the effect of Ectoine. part A: natural meibomian lipid films. Biochima et Biophysica Acta, 1838: 2708-2715, 2014.

Galinski EA, Pfeiffer HP, Trüper HG. 1,4,5,6-Tetrahydro-2methyl-4-pyrimidinecarboxylic acid. a novel cyclic amino acid from halophilic phototrophic bacteria of the genus Ectothiorhodospira. European Journal of Biochemistry, 149: 135-139, 1985.

Heinrich U, Garbe B, Tronnier H. In vivo assessment of Ectoin: a randomized, vehicle-controlled clinical trial. Skin Pharmacology Physiology, 20: 211-218, 2007.

Jablonski NG. Skin a natural history. University of California, Berkeley, California, pp93-105, 2012.

Kang HJ, Hah JH. A study on the hydration function of cutaneous stratum corneum. Korean Journal of Dermatology, 31: 890-895, 1993.

Kang HJ, Ham JH. Cutaneous hydration effects of moisturizers: urea, hydration base, petrolatum. Korean Journal of Dermatology, 34: 869-874, 1996.

Kim BY. Study on moisturing effect of trehalose. Journal of the Koran Society of Cosmetology, 2: 9-25, 1996.

Kim H, Jung M, Lim E, Jung H, Shin J, Hur Y. Verification of the efficiency of the skin improvement of air brush as a homecare device using whitening cosmeceutical ingredient. Journal of the Korean Society of Cosmetology, 24: 412-421, 2018.

Kwon MS, Choi TB. The effect on the skin barrier function of ceramide. Asian Journal of Beauty and Cosmetology, 3: 131-137, 2005.

Kwon HM, Kim KJ, Kim SY, Kim SH, Kim JK, Kim HS, Bom HJ, Jeon YS. Dermatology. Chenggu Culture History, Seoul, pp91-240, 2009.

Kwon SB, Lee GT, Choi SJ, Lee NK, Park HW, Lee KS, Lee KK, Ahn KJ, An IS. The effect of glycerin, hyaluronic acid and silicone oil on the hydration moisturization and transepidermal water loss in human skin. Asian Journal 
of Beauty and Cosmetology, 11: 761-768, 2013.

Kim YR, Cho SY, Seo DB, Kim SH, Lee SJ, Cho Y. Effects of oral intake of gromwell water fraction on ceramides content and the development of atopic dermatitis in NC/Nga mice. Korean Journal of Food Science and Technology, 41: 547-551, 2009.

Marini A, Reinelt K, Krutmann J, Bilstein A. Ectoine-containing cream in the treatment of mild to moderate atopic dermatitis: a randomised comparator-controlled, intra-individual double-blind, multi-center trial. Skin Pharmacology and Physiology, 27: 57-65, 2014.

Park CS. The skin barrier and moisturizer. The Journal of Skin Barrier Research, 9: 11-17, 2007.

Park EK, Kang SM, Lee MH. A study on the variation of skin moisture, oil (sebum), melanin and erythema index after application of $\beta$-glucan. Asian Journal of Beauty and Cosmetology, 1: 83-94, 2003.,

Salapatek A, Bates M, Bilstein A, Patel D. Ectoin ${ }^{\circledR}$, a novel, non-drug, extremophile-based device, relieves allergic rhinoconjunctivitis symptoms in patients in an environmental exposure chamber model. The Journal of Allergy and Clinical Immunology, 127: AB202, 2011.

Shin Jl, Kwon IO, Kim CY. Strategy for the treatment of infraorbital dark circles. Archives of Aesthetic Plastic Surgery, 17: 91-98, 2011.

Sohn ES, Kim SW, Kang JS, Lee SP. Technology trend and patent information analysis of cosmetic material derived from natural products. Applied Chemistry, 8: 466-469, 2004.

Whang WK, Lee YA, An HJ, Jo YK. Buying attitude on cosmetics of women with life style. Asian Journal of Beauty and Cosmetology, 8: 117-126, 2010.

Yi GJ, Moon KC, Kim SN. A study of skin responses produced by sodium laury sulfate and ethanol, and quantification of erythema using a chroma meter in healthy men. Journal of Dermatology, 30: 857-863, 1992. 


\section{국문초록}

\section{천연성분 Ectoin이 피부 보습 및 수분에 미치는 영향}

이새롬 ${ }^{1}$, 김영삼 ${ }^{2 *}$

${ }^{1}$ 건국대학교 향장학과, 서울, 한국

${ }^{2}$ 건국대학교 산업대학원 이미지산업학과, 서울, 한국

목적: 본 연구는 천연성분 Ectoin의 피부 보습, 모공, 피부색, $\mathrm{pH}$ 등에 미치는 전반적인 효과를 규명하고자 하였다. 방법: Ectoin 분말 추출 시료는 클렌징폼, 토너, 크림, 로션으로 제조하여 실험군과 대조군에게 매일 아침, 저녁으로 2 회씩 4 주간 안면에 사용하 도록 하였다. 수집된 자료는 통계 프로그램 SPSS 24.0 for Windows를 이용하여 분석하였다. 결과: 유분의 경우, 대조군은 T존과 U 존 모두에서 유분 증가가 나타난 반면, 실험군은 T존에서는 유분이 감소하였고, U존에서는 유분이 증가하였다. 수분의 경우, 대조 군과 실험군 모두 수분이 증가했지만, 모든 항목에서 대조군보다 실험군의 수분 함유량 증가가 크게 나타났으며, 실험군은 턱을 제 외한 모든 항목에서 수분이 유의하게 증가하였다. Transepidermal water loss (TEWL)의 경우, 대조군은 턱을 제외한 모든 항목에 서 TEWL이 증가했고, 실험군은 모든 항목에서 TEWL의 감소를 나타냈다. 모공의 경우, 대조군에서는 모공의 증가와 감소가 교차 하는 경향을 나타냈지만, 실험군에서는 모든 항목에서 모공의 감소를 나타냈다. $\mathrm{pH}$ 는 사전, 사후 모두 평균 4.5-6.5에 해당하는 피 부의 정상 $\mathrm{pH}$ 범주를 보였으며, 유의한 변화는 나타나지 않았다. 피부색의 경우, 대조군의 멜라닌은 증가와 감소가 교차하는 반면, 실험군의 멜라닌은 좌우 모두에서 유의한 감소를 나타냈고, 홍반은 대조군과 실험군 모두 감소를 나타냈으나, 실험군의 홍반이 대 조군에 비해 크게 감소하였다. 결론: 본 실험결과를 통해 천연성분인 Ectoin이 함유된 크림이 피부 보습 및 수분에 미치는 긍정적인 영향을 객관화, 수치화하였고, 이를 통해 화장품에 들어가는 천연 보습 원료로서의 가능성을 확인하였다.

핵심어: 수분, 경피수분손실량, Ectoin, 보습, 천연성분

\section{참고문헌}

강호정, 함정희. 수종 피부 질환에서 피부 각질층의 보습기능에 관한 연구. 대한피부과학회지, 31: 890-895, 1993. 강호정, 함정희. 수종의 보습기제의 피부보습효과에 관한 연구. 대한피부과학회지, 34: 869-874, 1996. 김봉인. Trehalose의 보습효과 연구. 한국미용학회지, 2: 9-25, 1996.

김영란, 조시영, 서대방, 김성한, 이상준, 조윤희. 자초 추출물 극성 성분의 피부 보습 증진 및 아토피 피부염 호전 효과. 한국식품과학회지, 41: 547-551, 2009.

김현정, 정민숙, 임은화, 정해성, 신정민, 허유경. 미백기능성 원료를 활용한 에어브러시의 홈케어 기기로써 피부개선 효용

성 연구. 한국미용학회지, 24: 412-421, 2018.

권민수, 최태부, 김기연. 세라마이드가 피부장벽 기능에 미치는 효과. 아시안뷰티화장품학술지, 3: 131-137, 2005. 권승빈, 이강태, 최성진, 이나경, 박현우, 이광식, 이건국, 안규중, 안인숙. 글리세린, 히알루론산, 실리콘 오일이 피부의

보습 및 경피수분손실량에 미치는 효과. 아시안뷰티화장품학술지, 11: 761-768, 2013.

권혁미, 김귀정, 김선옥, 김선희, 김재경, 김한식, 범희주, 전영선. 피부학. 청구문화사, 서울, $\mathrm{pp} 91-240,2009$. 박은경, 강상모, 임미혜. $\beta$-Glucan 적용 후 피부의 수분, 유분, 멜라닌 지수, 홍반지수 변화에 관한 연구. 아시안뷰티화장

품학술지, 1: 83-84, 2003.

박장서. 피부장벽과 보습제. 한국피부장벽학회지, 9: 11-17, 2007.

신종인, 권인오, 김창연. 눈밑 다크써클의 원인에 따른 치료접근법. 대한미용성형외과학회지, 17: 91-98, 2011.

손은수, 김상우, 강종석, 이상필. 천연물유래 화장품 소재의 기술개발동향 및 특허정보분석. 응용화학, 8: 466-469,

2004. 
이길주, 문기찬, 김수남. 건강한 성인에서 Sodium Lauryl Sulfate와 Ethanol에 의한 피부반응 및 Chroma Meter를 이용 한 홍반의 정량적 측정에 관한 연구. 대한피부과학회지, 30: 857-863, 1992.

장민열, 김진준, 이천구. 화장품과 보습제: 작용기전에 따른 보습제의 종류. 한국피부장벽학회지, 9: 18-26, 2007.

황완균, 이영애, 안희진, 조연경. 여성의 라이프 스타일에 따른 화장품 구매 태도. 아시안뷰티화장품학술지, 8: 117-126, 2010. 


\section{中文摘要}

\section{天然成分Ectoin对皮肤保湿和水分的影响}

李새롬 ${ }^{1}$ 金永三 ${ }^{2^{*}}$

${ }^{1}$ 建国大学化妆品工学科疾病分子靶标新药研究所, 首尔, 韩国

2建国大学产业大学院影像产业学科, 首尔, 韩国

目的：调查天然成分Ectoin对皮肤保湿，毛孔，肤色和 $\mathrm{pH}$ 值的影响。方法: Ectoin用于生产泡沫清洁剂，爽肤 水, 乳霜和乳液。向实验组和对照组分别提供含有或不含有Ectoin的化妆品样品, 并指示在早晨和晚上每天两 次, 将它们施用于面部, 持续4周。数据分析利用SPSS 24.0 for Windows统计软件进行。结果: 关于油份, 对 照组在T区和U区显示出油含量增加, 而实验组显示: T区的油含量降低，U区的油含量增加。关于水分，虽然两 组的水分含量均增加, 但是, 实验组在所有面部区域的水分含量均高于对照组。实验组显示: 除了下巴之外的 所有面部区域的水分含量的统计学显着增加。关于经表皮水分丢失(transepidermal water loss, TEWL), 对照 组在除下巴之外的所有面部区域表现出增加的TEWL值, 而实验组在所有面部区域显示出降低的TEWL值。毛孔 调查结果显示: 尽管对照组显示出孔径交替增加和减少的模式, 但实验组在所有面部区域显示出孔径减小。关 于 $\mathrm{pH}$ 水平，两组在实验之前和之后显示正常 $\mathrm{pH}$ 范围（4.5-6.5），没有任何统计学上显着的变化。关于肤色， 对照组显示黑色素交替增加和减少，而实验组显示在面部左侧和右侧黑色素的统计学显着降低。虽然两组均显 示红斑减少, 但实验组的红斑减少程度明显高于对照组。结论: 以上结果表明, 含有天然成分Ectoin的乳霜对 皮肤保湿和水分具有积极作用，因此，作为化妆品的天然保湿原料充分具有可行性。

关键词：水分，经皮水分丢失，Ectoin，保湿，天然成分 
